\title{
Impact of the Electric Mobility Implementation on the Greenhouse Gases Production in Central European Countries
}

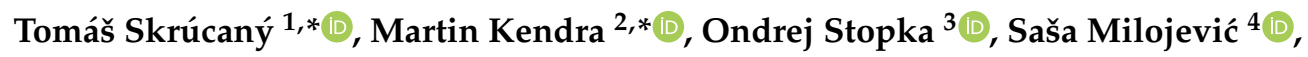 \\ Tomasz Figlus ${ }^{5}\left(\mathbb{D}\right.$ and Csaba Csiszár ${ }^{6}(\mathbb{C})$ \\ 1 Department of Road and Urban Transport, University of Žilina, Univerzitná 1, 01026 Žilina, Slovakia \\ 2 Department of Railway Transport, University of Žilina, Univerzitná 1, 01026 Žilina, Slovakia \\ 3 Department of Transport and Logistics, Institute of Technology and Business in České Budějovice, \\ Okružní 10, 37001 České Budějovice, Czech Republic \\ 4 Department for Motor Vehicles and IC Engines, University of Kragujevac, Sestre Janjić 6, \\ 34000 Kragujevac, Serbia \\ 5 Department of Transport, Silesian University of Technology, Krasińskiego 8, 40019 Katowice, Poland \\ 6 Department of Transport Technology and Economics, Budapest University of Technology and Economics, \\ Múegyetem rkp. 3, 1111 Budapest, Hungary \\ * Correspondence: tomas.skrucany@fpedas.uniza.sk (T.S.); martin.kendra@fpedas.uniza.sk (M.K.); \\ Tel.: +421-41-513-3518 (T.S.); +421-41-513-3429 (M.K.)
}

Received: 26 August 2019; Accepted: 9 September 2019; Published: 10 September 2019

\begin{abstract}
The preference and the development of electromobility are included among the priorities of transport policies in many European countries. This article deals with the issue of electric vehicle operation from the point of view of the environmental impact of electric power production, specifically the energy effectiveness of its production by utilizing primary power production sources. Differences in the effectiveness of the conversion of mixed forms of energy into electricity and their share in the process directly affect the final level of greenhouse gases (GHG) production, and thus the ecological footprint of electric vehicle operations. The specification of energy consumption and GHG production is based on the principles of the EN 16 258: 2012 standard, which considers legislative-regulated power plant effectiveness values, statistical values of GHG emissions from electricity production, and real energy consumption values of an electric vehicle fleet. The calculation takes into account the share of primary sources and the efficiency of electricity production and effectiveness of electricity distribution in each of the evaluated countries. The specific research study is performed by comparing measured parameters for individual countries chosen from the Central Europe region. The results of the study show that the quantification of the positive environmental consequences of increasing electromobility varies greatly in different countries, which means full-scale deployment of electromobility does necessarily deliver the sustainability of transport that was expected from it.
\end{abstract}

Keywords: environmental impact; electric mobility; greenhouse gas; primary sources; production efficiency; well-to-wheels approach

\section{Introduction}

Increasing transport volumes cause more negative impacts on the environment. One of these impacts is the air pollution problem caused by the burning of fossil fuels, agricultural activities, exhaust from factories and industries, and some other activities [1,2]. Global climate change is a very major global problem [3]. The Earth's surface temperature and ambient air temperature are reaching higher and more intense values more frequently than before [4]. Global warming and air pollution are largely 
caused by GHG. They are emitted by many anthropological activities like industrial and transport activities [5-7].

The European Union has a plan to reduce the amount of greenhouse gases (GHG) emissions by $20 \%$ [8]. This goal is determined in the strategy called European 20/20/20 objectives. The strategy was established in 2007 and has three targets: a $20 \%$ increase in energy efficiency, a $20 \% \mathrm{CO}_{2}$ emissions reduction and $20 \%$ renewable sources usage by $2020[9,10]$.

The legislative framework of the EU contains a goal to decrease $\mathrm{CO}_{2}$ emissions by at least $40 \%$ below 1990 levels by 2030 - the EU should introduce steps towards achieving targets (2050) involving reducing its $\mathrm{CO}_{2}$ footprint by $80 \%-95 \%$ [11-13].

The EU's Environmental White Paper covers those targets. Several other possibilities are also available to reduce transport volumes in the EU countries [14,15]. These include establishing more integrated and effective transport systems, supporting the introduction of modern technologies for vehicles and new types of fuel, and encouraging the use of environmentally friendly transport modes [16]. Aspects regarding sustainable transport and traffic in the EU are addressed, for example, in various publications [17-20].

The freight and passenger transport sector is expected to provide one of the largest contributions to the reduction of GHG emissions. In order to reduce emissions and diversify energy sources, alternative fuels have been promoted and suggested by a number of several particular methodologies at the national, EU, as well as global level, and have been discussed in a variety of research studies and publications [21-28].

Electromobility as a serious alternative to conventional mobility systems is gaining ground across the EU [29]. Between 2017 and 2018, the number of pure electric cars increased by 43 percent in EU. The increasing popularity of electric cars is due to falling battery costs, longer ranges, and a wider choice of models. Such development is expected to continue over the next several years with special subsidy packages, as addressed in references [30-32], and especially in reference [33].

For instance, some authors in their publications [34-37] state that the adoption of plug-in electric vehicles in Europe is actively supported by the European Union and several European governments have stipulated public subsidies and other non-financial incentives to promote their widespread adoption. More than one million plug-in electric passenger cars and vans (trucks) have been registered in Europe by June 2018 [38], the second largest stock after China [39].

The research studies presented by references $[27,40]$ state that to assess GHG emissions produced by electric vehicles and GHG savings in comparison with internal combustion engine vehicles, it is necessary to know the carbon intensity of electricity consumed by recharging batteries of electric vehicles. Legislation often relies on values and calculations based on the well-to-wheel methodology. Analogous or similar findings are outlined in references [41-44] as well.

Unlike a lot of previously published research studies only evaluating GHG production by the operation of electric vehicles from a regional perspective [45-47], some studies also take into account GHG production from the perspective of electricity generation $[48,49]$. The submitted manuscript takes into account the share of the primary sources in electricity production and the efficiency of electricity production and distribution as well. The authors also calculated the electricity consumption and GHG emissions based on actual readings of the real consumption of electric vehicles operated in real driving conditions, not based on theoretical consumption patterns declared by the producers of electric vehicles.

\section{Data, Methods, and Initial Calculations}

For the purpose of this research study, the following countries were taken into consideration: Austria (AT), the Czech Republic (CZ), Germany (DE), Hungary (HU), Poland (PL), Slovakia (SK) and Slovenia (SI).

This European Standard EN 16258: 2012 specifies a methodology for how to calculate and declare the energy intensity and GHG production in relation to transport operation. It defines relevant general 
principles, definitions, system boundaries, and methods of calculation. The standard does not only consider the production of the secondary emissions and energy consumed during the combustion of the fuel (energy conversion from fuel to mechanical energy), but also primary emissions, which are incurred in the extraction, production and distribution stages.

A well-to-wheels approach means "well on wheels" and includes primary as well as secondary emissions and consumption. This factor (approach) is also referred to as LCA (life-cycle-analysis).

A tank-to-Wheels approach (factor) covers only the secondary emissions and consumption.

Emission gases are composed of several individual components (gas).

Each gas has different chemical and physical properties, which means that they have diverse impacts on environmental degradation [50-52]. In particular, the $\mathrm{CO}_{2}$ equivalent, which represents an impact rate of specific emission types, is used to indicate the overall impact of $\mathrm{CO}_{2}$. This equivalent is denoted as $\mathrm{CO}_{2 \mathrm{e}}$.

Well-to-wheels factors used for electric power must be chosen from the specified data provided and have to involve previous operations according to the objectives of the mentioned standard, or they must be corrected in order to take into account the contribution of missing processes and gases [53-55].

The tank-to-wheels energy factor $\left(\mathrm{e}_{\mathrm{t}}\right)$ for electricity equals 3.6 MJ/kWh and the tank-to-wheels emissions factor $\left(g_{t}\right)$ for electricity is equal to zero [53].

\subsection{Energy Production}

The factors $(\mathrm{WtW})$ for energy and gases take into consideration the following partial aspects in the generation and distribution of electric power affecting the final value of the WtW or LCA factor:

(1) the composition of primary energy sources,

(2) the effectiveness of the individual sources used,

(3) the effectiveness of the transmission and distribution of the electricity.

The electric power generation technology, composition, and share of primary sources and distribution effectiveness have direct influence on the effectiveness of electricity generation (Figure 1).

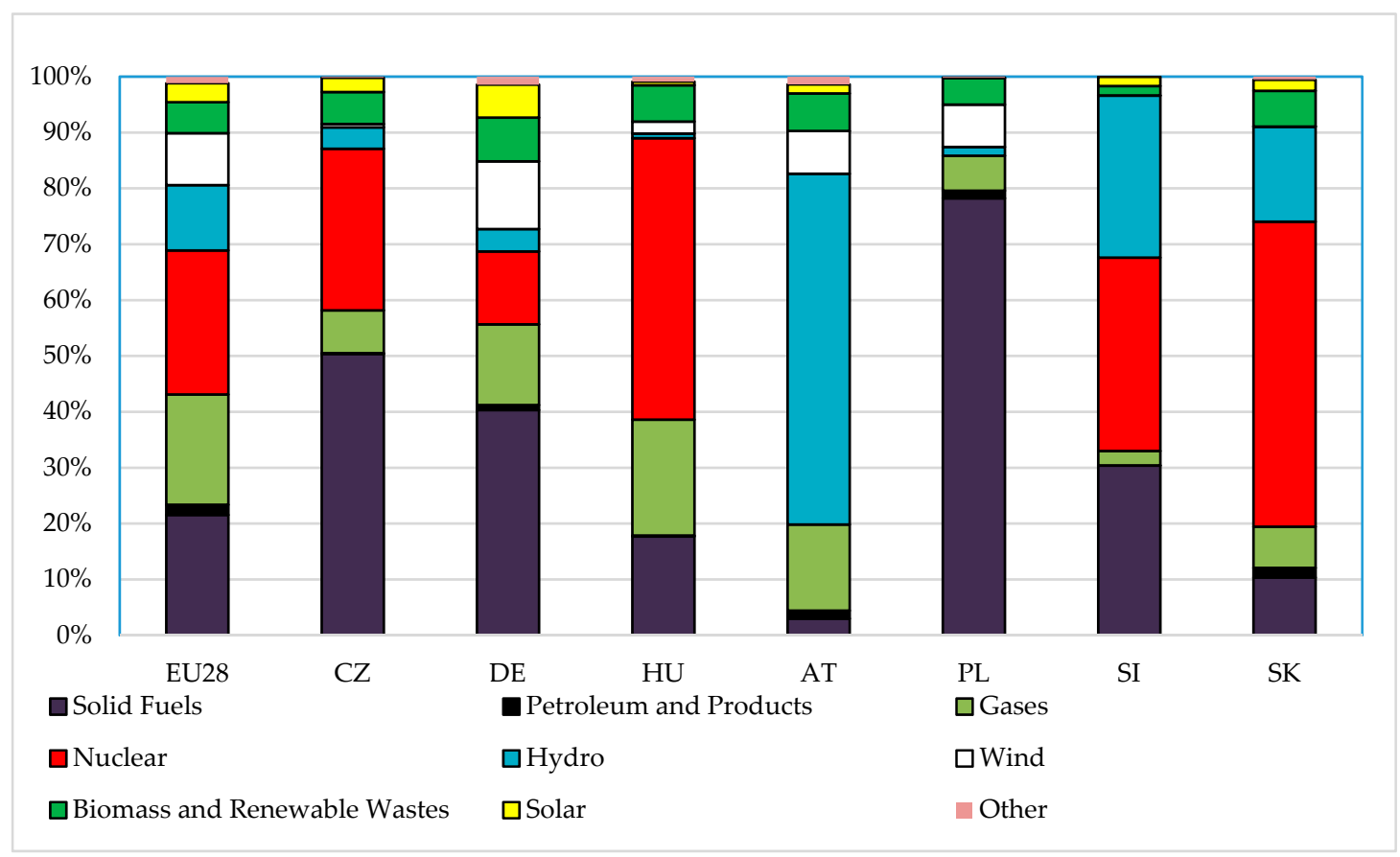

Figure 1. The ratio of energy sources during electricity power production in Central Europe countries in 2016 [56]. 
The efficiency of electric power generation is determined as a weighted arithmetic mean of the ratio of energy sources and the efficiency of each source during electricity energy production. The weights of values represent the shares of individual sources. Values of effectiveness were obtained from the International Atomic Energy Agency Bulletin [57].

The energy generated is distributed to the grid through the transmission branch system. This process is operated with losses (energy branch consumption). Electric power distribution effectivity in the grid of the Central Europe countries was at levels varying from 84\% (Poland) to 93\% (Slovenia) [56].

The total energy effectiveness of consumed electric power in transport is as follows [55]:

$$
\eta=\eta_{\text {Prod }} \cdot \eta_{\text {Trans }} \cdot \eta_{\text {Veh }}=\frac{\sum\left(\eta_{S i} \cdot p_{S i}\right)}{\sum p_{S}} \cdot \eta_{\text {Trans }} \cdot \eta_{\text {Veh }}(-)
$$

where:

$\eta$ final energy effectiveness (-)

$\eta_{\text {Prod }}$ effectiveness of electric power (-)

$\eta_{\text {Trans }}$ effectiveness of transmission (-)

$\eta_{\text {Veh }}$ effectiveness of vehicle system (-)

$\eta_{S i}$ effectiveness of a particular primary source (-)

$p_{S i}$ share of a particular primary source (-)

$p_{S}$ sum of partial shares of individual sources (-)

According to the above mentioned facts and their real composition in Central Europe countries, electric power generation usually has effectiveness levels varying from $31 \%$ (Hungary) to $63 \%$ (Austria). As far as electricity production in Central European countries is concerned, the values from the Decree regulating the lowest efficiencies of operated power plants were used as input data [58]. Chosen values of effectiveness are given in Table 1 . A chart representing the efficiency of electricity production in the Central European countries is depicted in Figure 2.

Table 1. Values of energy conversion effectiveness.

\begin{tabular}{|c|c|c|c|c|c|}
\hline \multirow{2}{*}{$\begin{array}{c}\text { Electricity } \\
\text { Producing } \\
\text { Device }\end{array}$} & \multirow[b]{2}{*}{ Fuel } & \multirow[b]{2}{*}{$\begin{array}{c}\text { Electric Power } \\
\text { (MW) }\end{array}$} & \multicolumn{3}{|c|}{ Year of Introducing the Plant } \\
\hline & & & before 1998 & $\begin{array}{c}\text { 1998-2012 } \\
\text { Efficiency (\%) }\end{array}$ & 2013-2015 \\
\hline \multirow{12}{*}{$\begin{array}{l}\text { Combustion } \\
\text { device and } \\
\text { condensing } \\
\text { steam turbine }\end{array}$} & \multirow{3}{*}{ black coal } & to 15 & 36 & 36 & 38 \\
\hline & & from 15 incl. to 50 & 38 & 38 & 40 \\
\hline & & 50 and higher & 39 & 39 & 41 \\
\hline & \multirow{3}{*}{ brown coal } & to 15 & 35 & 35 & 37 \\
\hline & & from 15 incl. to 50 & 37 & 37 & 39 \\
\hline & & 50 and higher & 38 & 38 & 40 \\
\hline & \multirow{3}{*}{ natural gas } & to 10 & 38 & 38 & 40 \\
\hline & & from 10 incl. to 35 & 40 & 40 & 42 \\
\hline & & 35 and higher & 41 & 41 & 43 \\
\hline & \multirow{3}{*}{ heavy fuel oil } & to 15 & 36 & 36 & 38 \\
\hline & & from 15 incl. to 50 & 38 & 38 & 40 \\
\hline & & 50 and higher & 39 & 39 & 41 \\
\hline \multirow{6}{*}{$\begin{array}{l}\text { Heat source } \\
\text { and condensing } \\
\text { steam turbine }\end{array}$} & \multirow{3}{*}{ nuclear } & to 500 & 31 & 31 & 32 \\
\hline & & from 500 incl. to 1000 & 31 & 31 & 32 \\
\hline & & 1000 and higher & 31 & 31 & 32 \\
\hline & heat from & to 10 & 36 & 36 & 36 \\
\hline & industrial & from 10 incl. to 35 & 36 & 36 & 36 \\
\hline & processes & 35 and higher & 36 & 36 & 36 \\
\hline $\mathrm{ICE}$ & Natural gas & to 0.05 & 29 & 29 & 29 \\
\hline
\end{tabular}

Source: [58], calculated by authors. 


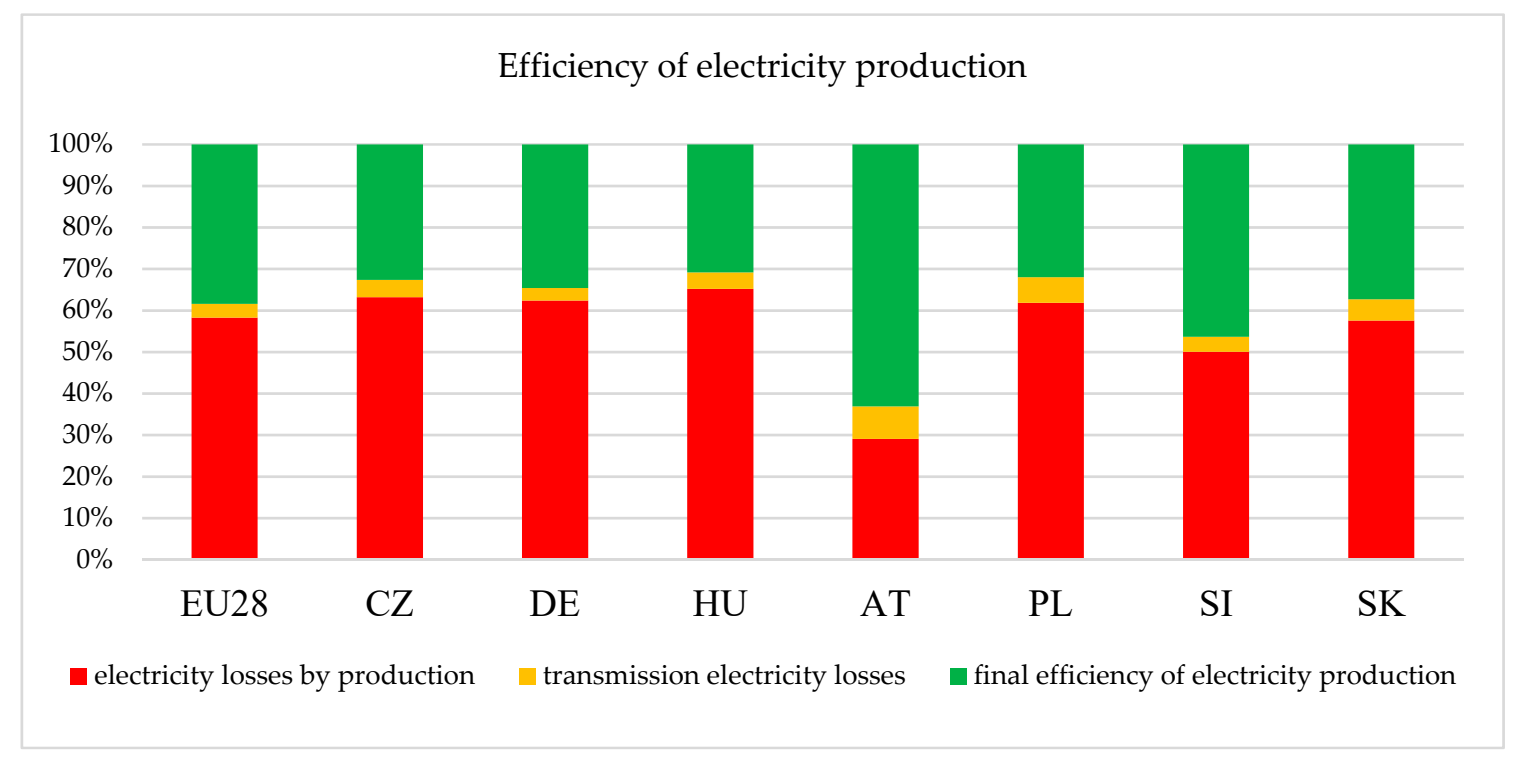

Figure 2. The electricity production efficiency [56].

Following the values in Table 1 and Figure 2 above, it can be stated that $324 \mathrm{kWh}$ of energy generated from primary sources in Hungary and $158 \mathrm{kWh}$ in Austria must be produced for every $100 \mathrm{kWh}$ of consumed electricity. Individual source efficiency is approximately $15 \%$ for solar plants, through $35 \%$ and $40 \%$ for fossil fuels plants, and up to $85 \%$ for hydroelectric plants $[59,60]$.

Table 2 compares the energy intensity of electricity production in Central European countries. For the final customer to use 100 MJ of energy (which is $28 \mathrm{~kW}$ ) for vehicle battery charging, between 44.4 $\mathrm{kWh}$ in Austria to $90.7 \mathrm{kWh}$ in Hungary must be consumed from primary sources.

Table 2. Comparison of energy intensity of electricity production in Central European countries.

\begin{tabular}{ccccc}
\hline Output & $\begin{array}{c}\text { Direct Energy } \\
\text { Consumption (MJ) }\end{array}$ & $\begin{array}{c}\text { Direct Energy } \\
\text { Consumption (kWh) }\end{array}$ & Country & $\begin{array}{c}\text { Overall Energy } \\
\text { Consumption (W-t-W) (kWh) }\end{array}$ \\
\hline & & EU28 & 72.9 \\
& & CZ & 85.7 \\
Electricity & \multirow{2}{*}{28} & $\mathrm{DE}$ & 80.9 \\
& & & $\mathrm{HU}$ & 90.7 \\
& & $\mathrm{AT}$ & 44.4 \\
& & $\mathrm{PL}$ & 87.5 \\
& & $\mathrm{SI}$ & 60.4 \\
& & $\mathrm{SK}$ & 75.0 \\
\hline
\end{tabular}

Source: references [53-56], calculated by authors.

\subsection{Emissions Production}

The calculation of emissions production in electricity generation is based on the calculated LCA emission factor, which has been set for each country separately. Its values for 2005, 2010, and 2016 are shown in Table 3 and are graphically illustrated in Figure 3. The LCA emission factor for 2005 and 2010 was taken from reference [61]. The LCA emission factor for 2016 was calculated on the basis of:

(1) changes in the ratio of primary sources used in electricity generation,

(2) estimated changes in the efficiency of electric power generation from all sources,

(3) the effectiveness of the transmission and distribution of electric power in each country. 
Table 3. Progress of the LCA emission factor in Central European countries in 2005, 2010, and 2016.

\begin{tabular}{ccccccccc}
\hline \multicolumn{8}{c}{ LCA Emission Factor $\left(\mathrm{gCO}_{\mathbf{2 e}} / \mathbf{k W h}\right)$} \\
\hline Year & EU28 & CZ & DE & HU & AT & PL & SI & SK \\
\hline 2005 & 588 & 819 & 709 & 675 & 346 & 1262 & 580 & 406 \\
2010 & 565 & 786 & 692 & 634 & 301 & 1153 & 631 & 334 \\
2016 & 494 & 754 & 657 & 558 & 200 & 1061 & 598 & 292 \\
\hline \multicolumn{7}{c}{ Sources: references [56,62], calculated by authors. }
\end{tabular}

Sources: references [56,62], calculated by authors.

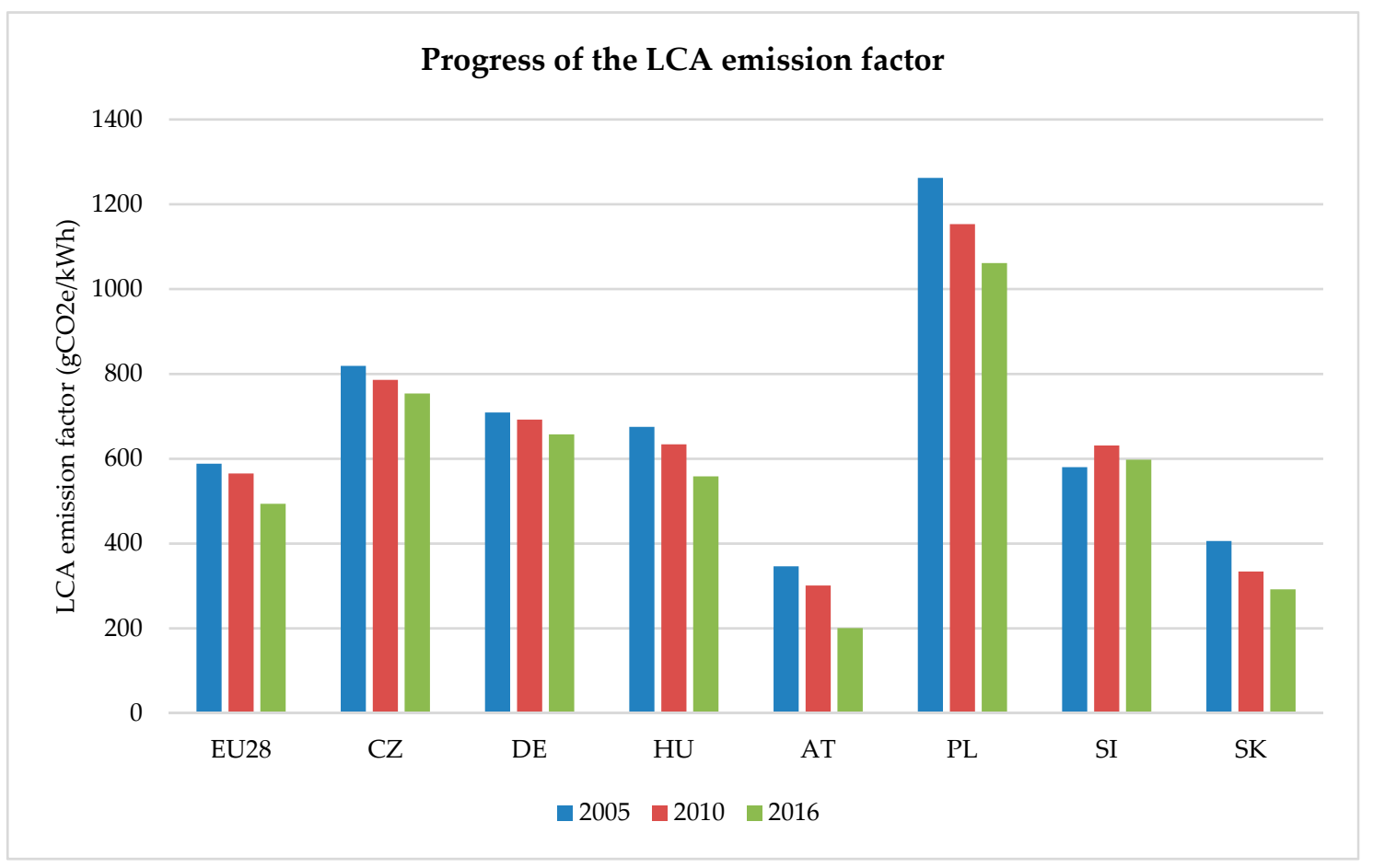

Figure 3. Progress of the LCA emission factor in Central European countries in 2005, 2010, and 2016. Sources: [56,62], calculated by authors.

The statistics data for these calculations was taken from reference [56].

The LCA emission factor has shown a decreasing trend in all Central European countries except for Slovenia. The decrease between 2005 and 2016 ranges from 7\% in Germany to $42 \%$ in Austria. This is evidence that the efficiency of electricity production and its distribution in each country is gradually increasing.

\section{Results Regarding the Energy Consumption and the GHG Production of Electric Vehicles}

The calculation of the electricity consumption and GHG emissions is based on actual readings of the real consumption of electric vehicles driven in real conditions, which are registered in the database [63]. It includes the data for 420 electric vehicles. Individual results of the calculations for the year 2016 are summarized in Table 4 and in Figures 4 and 5. 
Table 4. Comparison of energy intensity and the GHG production of electric vehicles in Central European countries for 2016.

\begin{tabular}{|c|c|c|c|c|c|c|c|}
\hline \multirow[b]{2}{*}{$\begin{array}{l}\text { Vehicle } \\
\text { Drive }\end{array}$} & \multirow[b]{2}{*}{ Country } & \multirow[b]{2}{*}{$\begin{array}{c}\varnothing \text { Energy } \\
\text { Consumption } \\
(\mathbf{k W h} / \mathbf{1 0 0 k m )}\end{array}$} & \multicolumn{3}{|c|}{$T-t-W$} & \multicolumn{2}{|c|}{$W-t-W$} \\
\hline & & & $\begin{array}{c}\text { Energy } \\
\text { Consumption } \\
(\mathrm{MJ} / \mathbf{k m})\end{array}$ & $\begin{array}{c}\text { Energy } \\
\text { Consumption } \\
(\mathbf{k W h} / \mathbf{k m})\end{array}$ & $\begin{array}{l}\text { Production of } \\
\mathrm{CO}_{2 \mathrm{e}}(\mathrm{g} / \mathrm{km})\end{array}$ & $\begin{array}{c}\text { Energy } \\
\text { Consumption } \\
(\mathrm{MJ} / \mathrm{km})\end{array}$ & $\begin{array}{c}\text { Production } \\
\text { of } \mathrm{CO}_{2 \mathrm{e}} \\
(\mathrm{g} / \mathrm{km})\end{array}$ \\
\hline \multirow{19}{*}{ Electric } & & 14.2 & 51.12 & 0.142 & \multirow{19}{*}{0} & 133.12 & 48.14 \\
\hline & EU28 & 16.8 & 60.48 & 0.168 & & 157.50 & 56.95 \\
\hline & & 21.2 & 76.32 & 0.212 & & 198.75 & 71.87 \\
\hline & & 21.2 & 76.32 & 0.212 & & 233.39 & 115.12 \\
\hline & & 14.2 & 51.12 & 0.142 & & 147.75 & 69.15 \\
\hline & $\mathrm{DE}$ & 16.8 & 60.48 & 0.168 & & 174.80 & 81.82 \\
\hline & & 21.2 & 76.32 & 0.212 & & 220.58 & 103.24 \\
\hline & & 14.2 & 51.12 & 0.142 & & 165.44 & 41.89 \\
\hline & AT & 16.8 & 60.48 & 0.168 & & 95.85 & 23.35 \\
\hline & & 21.2 & 76.32 & 0.212 & & 120.95 & 29.47 \\
\hline & & 14.2 & 51.12 & 0.142 & & 159.75 & 114.31 \\
\hline & PL & 16.8 & 60.48 & 0.168 & & 189.00 & 135.24 \\
\hline & & 21.2 & 76.32 & 0.212 & & 238.50 & 170.66 \\
\hline & & 14.2 & 51.12 & 0.142 & & 110.17 & 46.58 \\
\hline & SI & 16.8 & 60.48 & 0.168 & & 130.34 & 55.10 \\
\hline & & 21.2 & 76.32 & 0.212 & & 164.48 & 69.54 \\
\hline & & 14.2 & 51.12 & 0.142 & & 137.05 & 24.85 \\
\hline & SK & 16.8 & 60.48 & 0.168 & & 162.14 & 29.40 \\
\hline & & 21.2 & 76.32 & 0.212 & & 204.61 & 37.10 \\
\hline
\end{tabular}

Source: references [56,62,63], calculated by authors.

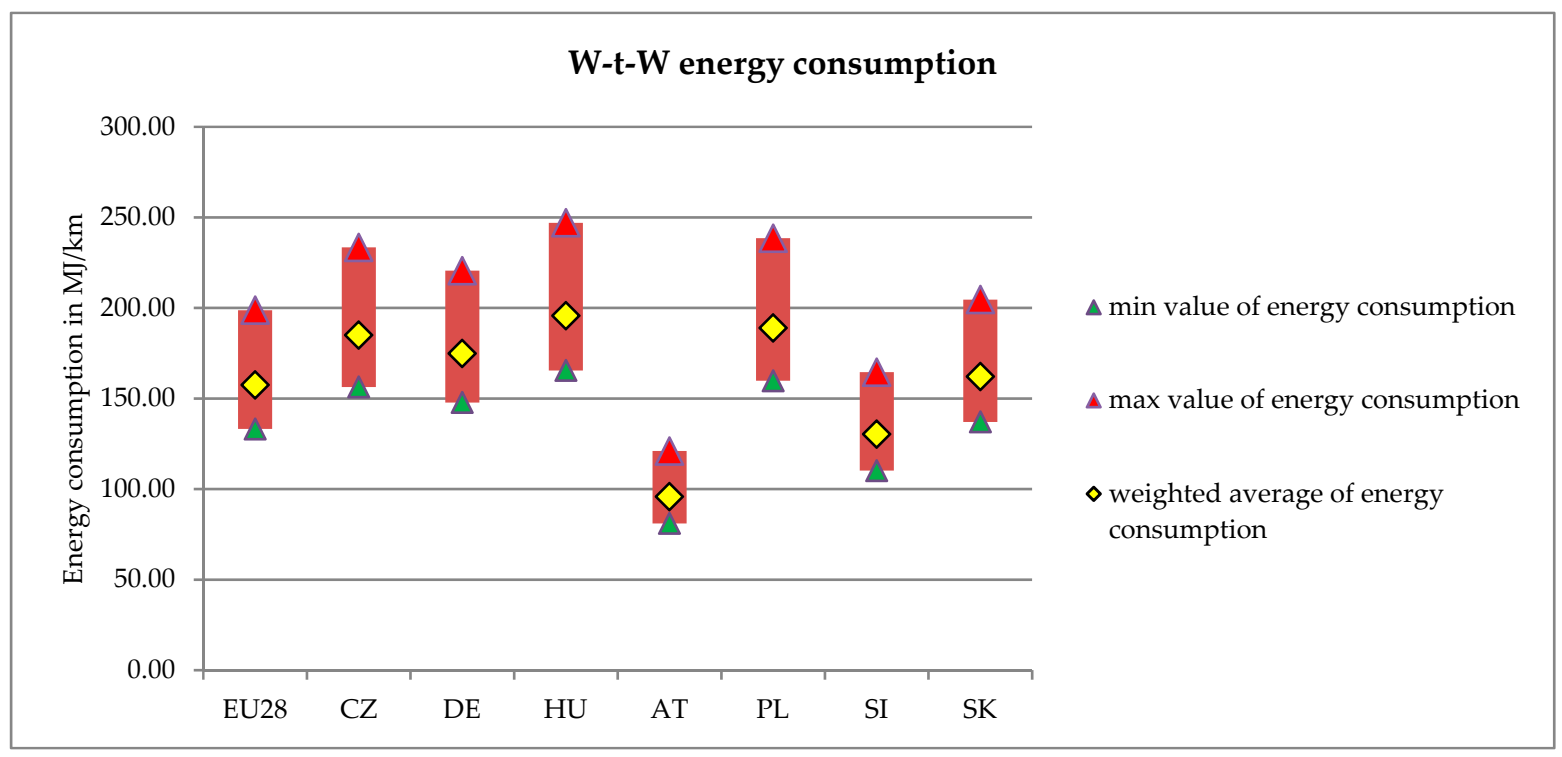

Figure 4. Well-to-wheel energy consumption of electric drive vehicles in Central European countries Sources: [56,62,63], calculated by authors.

The electricity consumption of all registered electric vehicles ranged from 14.2 to $21.2 \mathrm{kWh} / 100 \mathrm{~km}$. The weighted arithmetic average of the electricity consumption for all registered electric vehicles was $16.8 \mathrm{kWh} / 100 \mathrm{~km}$. 
Tank-to-wheel electricity consumption is the same for all Central European countries and ranges from $51.12 \mathrm{MJ} / \mathrm{km}(0.142 \mathrm{kWh} / \mathrm{km})$ to $76.32 \mathrm{MJ} / \mathrm{km}(0.212 \mathrm{kWh} / \mathrm{km})$ with a weighted arithmetic average of $60,48 \mathrm{MJ} / \mathrm{km}(0.168 \mathrm{kWh} / \mathrm{km})$.

Tank-to-wheel GHG production is zero.

Well-to-wheel energy consumption is different in each country. The lowest values are obtained in Austria (weighted average is $95.85 \mathrm{MJ} / \mathrm{km}$ ) and the highest values are in Hungary (weighted average is $195.73 \mathrm{MJ} / \mathrm{km}$ ). Most Central European countries have values of weighted arithmetic average consumption between approximately 162 and $196 \mathrm{MJ} / \mathrm{km}$.

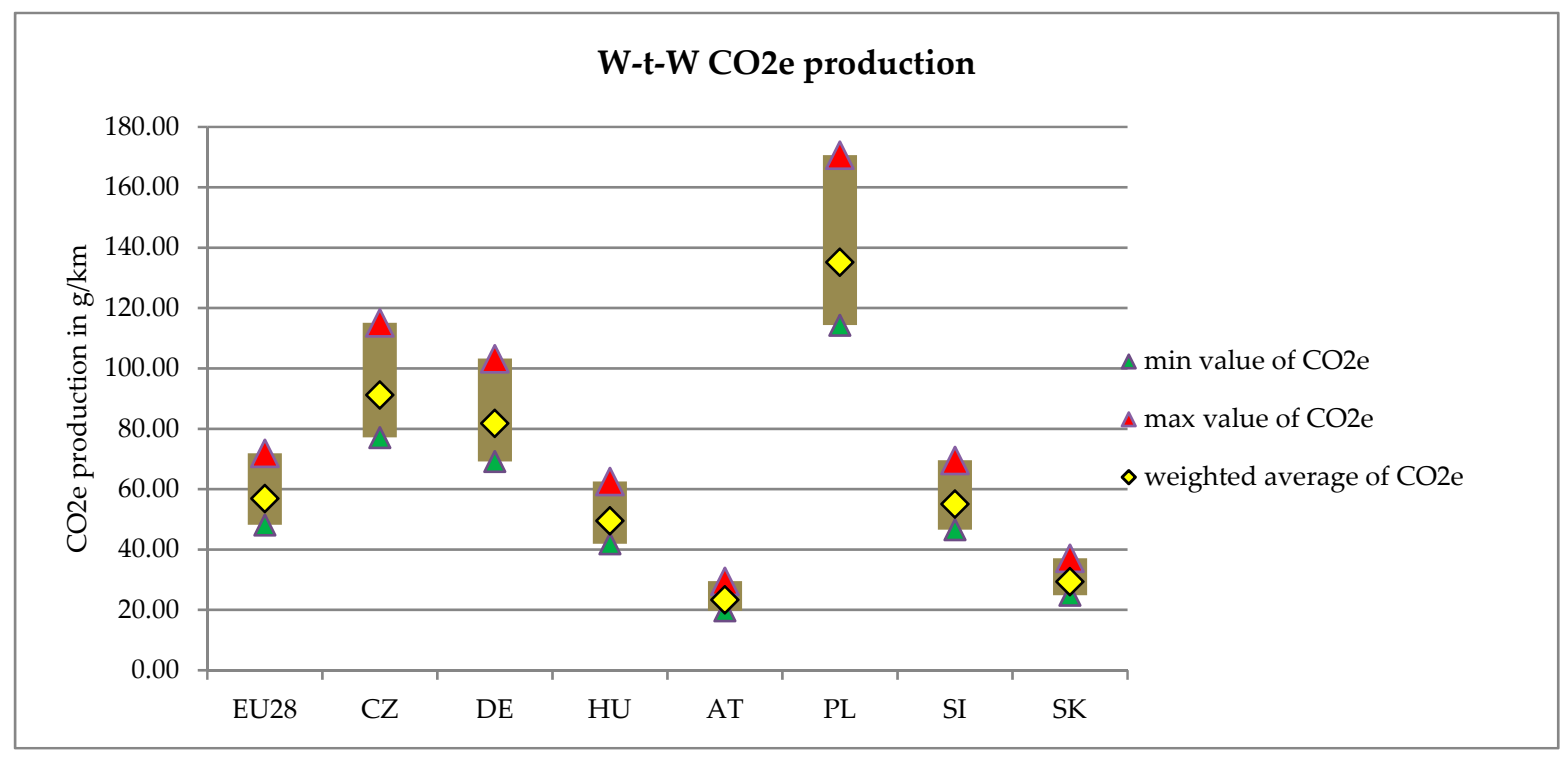

Figure 5. Well-to-wheel GHG production of electric drive vehicles in Central European countries for the year 2016. Sources: $[56,62,63]$, calculated by authors.

Well-to-wheel GHG production is calculated (Table 4 and Figure 5) from the LCA Emission Factor value from the year 2016. GHG production values vary widely between countries. The lowest values are obtained in Austria (weighted arithmetic average of $23.35 \mathrm{gCO} 2 \mathrm{e} / \mathrm{km}$ ) and Slovakia (weighted arithmetic average $29.40 \mathrm{gCO}_{2 \mathrm{e}} / \mathrm{km}$ ), the highest values are in Poland (weighted arithmetic average $\left.135.24 \mathrm{gCO}_{2 \mathrm{e}} / \mathrm{km}\right)$.

\section{Discussion}

The results achieved in this study show that it is not generally possible to claim that the use of electric vehicles in transport is always an environmentally friendly mode of transport. From a local point of view, the operation of electric vehicles can be considered environmentally friendly, since the operation itself does not produce GHG. However, taking into account the generation and distribution of electricity in individual countries, this study shows quite different results. As can be seen from Figure 2, the overall energy consumption (well-to-wheel) of electric vehicles in individual countries is strongly influenced by electricity production efficiency, which ranges from $31 \%$ in Hungary to $63 \%$ in Austria. This efficiency depends on primary energy sources and electricity production technology. Another difference in the efficiency of electricity used in transport also depends on losses in electricity distribution. These losses range from $7 \%$ (Slovenia) to 16\% (Poland) in the analyzed countries. These results indicate that the same electric vehicle that would run under the same operating conditions, but would be charged in different countries, would consume significantly different amounts of energy from primary sources. In Austria, this amount would be 81.01-120.95 MJ/km, while in Hungary it would be $165.44-249.99 \mathrm{MJ} / \mathrm{km}$, which is approximately twice the amount (Figure 4). 
The results of this study showed even greater differences in the assessment of the environmental performance of electric vehicles in individual countries, when the amount of produced GHG was monitored to produce the necessary electricity from different primary sources in these countries. As can be seen from Figure 5, the total amount of GHG produced in each Central European country generated by the electricity generation required to operate the same electric vehicle on the same track under the same operating conditions is in the range of 19.74-29.47 $\mathrm{gCO}_{2 \mathrm{e}} / \mathrm{km}$ in Austria to 114.31-170.66 $\mathrm{gCO}_{2 \mathrm{e}} / \mathrm{km}$ in Poland. This is a difference of up to 5.8 times.

The previous results can also be interpreted as follows. With the same amount of consumed primary energy, an electric car charged in Austria can travel approximately double the distance of the same car charged in Hungary. An electric vehicle charged in Poland has the same carbon footprint at a 5.8 times shorter distance than the same vehicle charged in Austria.

An author's collective has done a research study [64] which compared the energy intensity and GHG production of different propulsions (driving mechanism) installed in passenger cars. Table 5 summarizes the results of the environmental impact of conventional passenger cars with a gross weight of $1500 \mathrm{~kg}$ and equipped with several types of internal combustion engines (ICE) as well as an electric engine with approximately $80 \mathrm{~kW}$ of output power. Consumption declared by the manufacturer in the combined NEDC (New European Driving Cycle) is taken into account.

Table 5. Energy intensity and GHG production of cars with different types of propulsion.

\begin{tabular}{|c|c|c|c|}
\hline \multirow{2}{*}{ Energy Source } & \multirow{2}{*}{$\begin{array}{c}\text { FC and FE } \\
(1, \mathrm{~kg}, \mathrm{kWh} / 100 \mathrm{~km})\end{array}$} & \multicolumn{2}{|c|}{ W-t-W } \\
\hline & & $\begin{array}{l}\text { Energy Consumption } \\
(\mathrm{MJ} / \mathbf{1 0 0 k m})\end{array}$ & Production $\mathrm{CO}_{2 \mathrm{e}}(\mathrm{g} / \mathrm{km})$ \\
\hline Gasoline & 5.6 & 211 & 161 \\
\hline CNG & 4.4 & 220 & 135 \\
\hline Diesel & 4.4 & 188 & 143 \\
\hline electricity * & 20 & $114-233$ & $28-161$ \\
\hline hybrid ** & 4 & 151 & 115 \\
\hline
\end{tabular}

Table 5 shows the fact that vehicles equipped with an ICE engine produce less GHG compared to e-vehicles charged by electric power produced in Poland. Also, the energy efficiency of an ICE driven car is higher than an e-vehicle operated in Hungary. We can consider the actual scenario in implementation of electric vehicles in EU. The EV30@30 Scenario takes into account the commitment of the Electric Vehicle Initiative's EV30@30 Campaign to reach a 30\% market share for electric vehicles in all modes of transport except for two-wheelers in the European Union by 2030 [65]. Considering this fact, a higher number of operated electric vehicles consume a higher amount of electric energy. It is necessary to ensure that a more efficient level of electricity generation occurs. This can be achieved through two possible scenarios. The first one lies in the fact that countries will use the theoretical maximum capacity of electricity generation available from already existing plants; and the second one involves countries constructing advanced, innovative, more effective, and environmentally friendly plants.

Figure 6 presents the actual theoretical useable capacity (TUC) of installed plants in chosen countries colored by their share of energy sources. The free capacity (FC) of existing plants is also shown. The implementation of electric vehicles also creates higher electricity consumption. The increase of consumption depends on the number of vehicles, their average energy consumption, and their driving performance. 


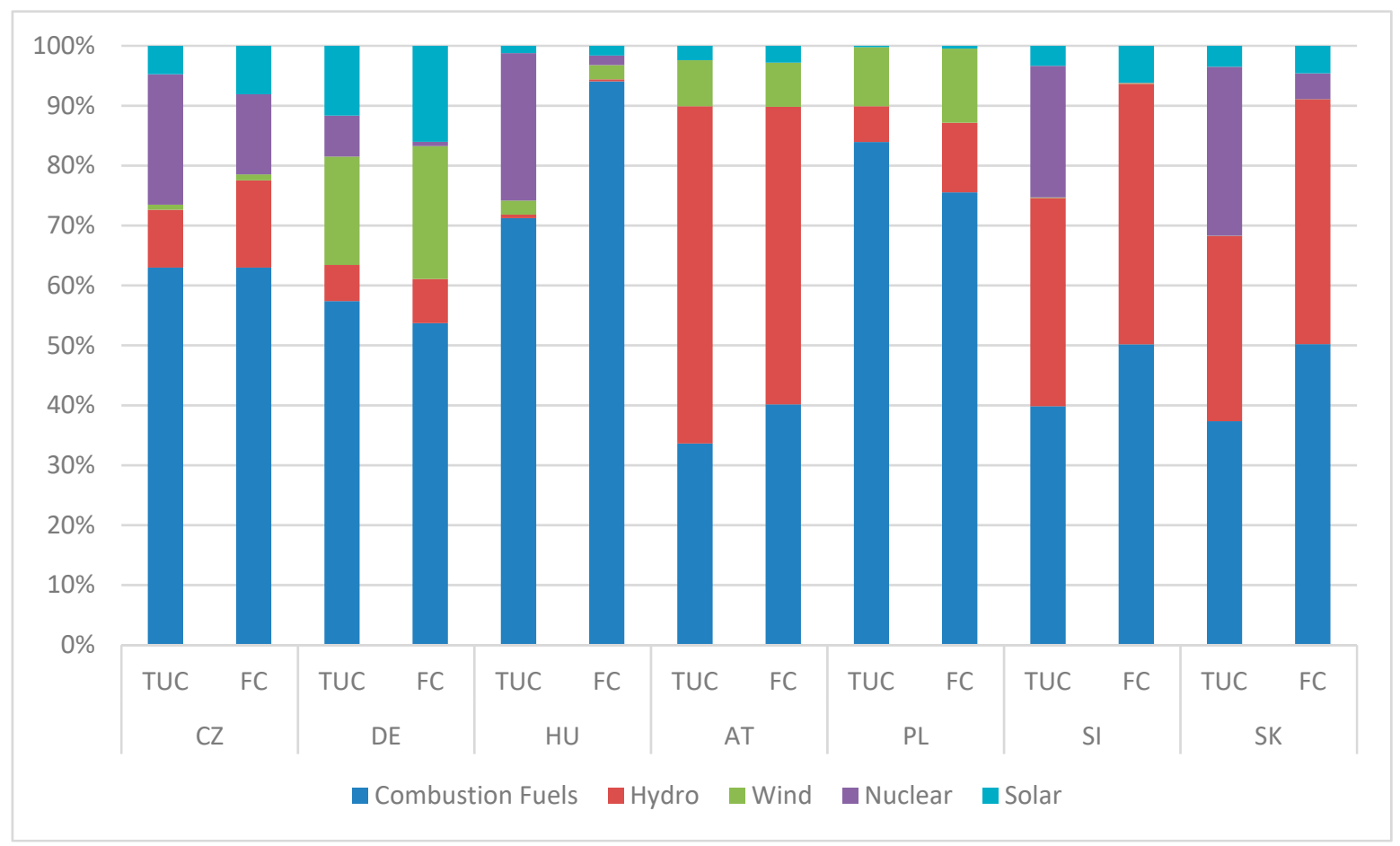

Figure 6. Theoretical useable capacity and free capacity of energy sources. Sources: reference [66], calculated by authors; TUC $=$ Theoretical useable capacity of energy sources; FC $=$ Free capacity of energy sources.

Let it be considered that up to $30 \%$ of all registered passenger cars in Slovakia are already purchased and in use. The average energy consumption of a reference (sample) vehicle is $17 \mathrm{kWh}$ per $100 \mathrm{~km}^{-1}$ with an average annual distance traveled of $15,000 \mathrm{~km}$. In this case, the electricity production must increase by approximately 3\%. Free capacity is higher in all the given countries (around $50 \%$ of TUC). It is possible to identify which countries can produce electricity with more or less GHG production intensity. For example, countries like Germany or Poland could provide more environmental friendly electricity production by using the TUC. Czech Republic and Slovenia could produce electricity without significant changes, and Slovakia, Austria and Hungary could produce more $\mathrm{kg}$ of $\mathrm{CO}_{2}$ per $\mathrm{kWh}$ of generated electricity. It seems like that there is no reason to construct new power plants; instead, only better utilization of existing ones is needed. Limitations of this calculation consist in simplifying the methodology of TUC specification (the best natural and technical conditions) as well as in considering the average annual energy consumption of electric vehicles. TUC can be insufficient in peak hours during the charging higher numbers of vehicles from the distribution network.

Development trend concerning the energy source distribution for electricity production which is characterized by a decrease in production of solid fuels is depicted in Figure 7.

In line with the above figure, effort is being put toward increasing the share of renewable sources. Such a fact as well as a decrease in production of solid fuels is causing the lower numbers in GHG production from electric power, which is described in more detail in Table 3. Electricity and its use in transport operation has become more environmentally friendly (especially compared to ICE vehicles) which helps to fulfill targets related to green transport. 


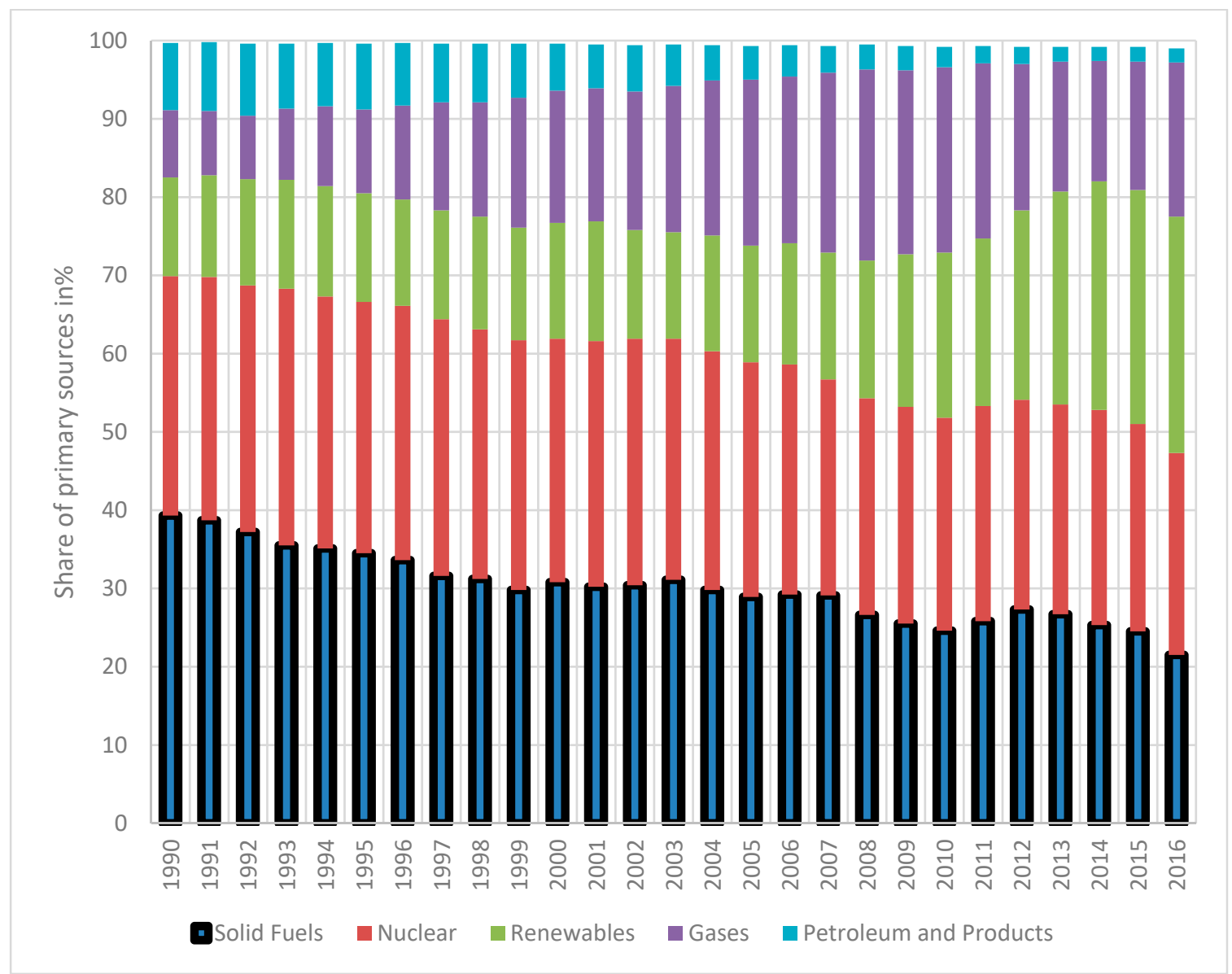

Figure 7. Trend of the energy source distribution in EU28. Sources: reference [66], calculated by authors.

The strength and innovation of this study lies in presentation of the differences among particular environmental impacts of the transport electrification according to each Central European country. These outcomes are provided in regards to an energy mix of the electricity production and distribution losses. The input data includes actual statistical numbers from real energy mix structure and actual electric power consumption declared by e-car users and manufacturers. The limitations of this research study results are above all in the accuracy of the implemented LCA factor data. These values are located in a wider range depending on different data sources. Even the average representative values were taken into account for calculations; and thus, there is a possibility of differences in results compared to other analogous studies. Despite the fact that the data related to the vehicle energy consumption are from real operations, the number of operated e-vehicles is extremely low (less than $1 \%$ of all registered vehicles) and therefore even our statistical sample is low. And also, this data do not take into account the vehicle battery charging losses. These attributes differ depending on the charging time and the type of charging device. These facts can affect the resulting values when comparing the real environmental impacts.

This study only takes into account the share of the primary sources, which are used in individual countries to produce electricity. It does not take into account the possibility of buying the electricity from other countries.

\section{Conclusions}

Although the Tank-to-Wheel electricity consumption of electric vehicles is the same for all countries, Well-to-Wheel consumption is different in each country and depends on the composition 
and ratio of the primary sources of electricity production, the electricity generation technology used, and the distribution efficiency in the electrical network to the final customer.

There is a similar situation for well-to-wheel GHG production as well. Although no GHG emissions are produced directly by the operation of electric vehicles, power generation produces large amounts of GHG emissions at power plants. Specific GHG values are dependent on the power generation technology.

The combination of inefficient generation of electricity from primary sources, where a large amount of GHG is produced and the use of a large-scale electricity transmission system may make the use of electric vehicles less environmentally friendly—from the vehicle operation point of view-or even disadvantageous in some countries.

In some countries in the region of Central Europe, the efficiency of energy consumption from the primary sources for the end users is half compared to countries with the highest efficiency. In terms of GHG production there is a difference up of to 5.8 times.

The implementation of a transport policy that prefers the development of electromobility would not have the same ecological impact in each country. Electric vehicle charging from a grid, e.g., in Poland is not as ecologically friendly as an electric car charged in Austria. Therefore, it is important that country leaders should focus not only on the implementation of electromobility itself, but they also have to develop ecologically friendly form of electricity generation and increase the effectiveness of electricity transmission.

Author Contributions: Conceptualization, T.S. and M.K.; methodology, T.S. and M.K.; validation, T.S., M.K. and O.S.; formal analysis, T.S., M.K. and O.S.; investigation, T.S. and M.K.; resources, T.S., M.K. and O.S.; data curation, T.S., M.K., O.S., S.M., T.F. and C.C.; writing-original draft preparation, T.S. and M.K.; writing-review and editing, T.S., M.K. and O.S.; visualization, T.S. and M.K.; supervision, O.S.; project administration, T.S.; funding acquisition, T.S.

Funding: This research was funded by University of Žilina, grant system UNIZA, name of the research: Assessment of energy consumption and GHG production of transport from the regional and global point of view.

Acknowledgments: This manuscript was supported within solving the research project entitled "Autonomous mobility in the context of regional development LTC19009" of the INTER-EXCELLENCE program, the VES 19 INTER-COST subprogram.

Conflicts of Interest: The authors declare no conflict of interest.

\section{References}

1. Knez, M.; Matjaz, K.; Tariq, M.; Jereb, B.; Cullinane, K. The estimation of a driving cycle for Celje and a comparison to other European cities. Sustain. Cities Soc. 2014, 11, 56-60. [CrossRef]

2. Sarkan, B.; Caban, J.; Marczuk, A.; Vrabel, J.; Gnap, J. Composition of exhaust gases of spark ignition engines under conditions of periodic inspection of vehicles in Slovakia. Przem. Chem. 2017, 96, 675-680.

3. Yang, L.; Wang, Y.; Han, S.; Liu, Y. Urban transport carbon dioxide $\left(\mathrm{CO}_{2}\right)$ emissions by commuters in rapidly developing Cities: The comparative study of Beijing and Xi'an in China. Transp. Environ. 2019, 68, 65-83. [CrossRef]

4. Petro, F.; Konecny, V. Calculation of emissions from transport services and their use for the internalisation of external costs in road transport. Proc. Eng. 2017, 192, 677-682. [CrossRef]

5. Lebkowski, A. Studies of Energy Consumption by a City Bus Powered by a Hybrid Energy Storage System in Variable Road Conditions. Energies 2019, 12, 951. [CrossRef]

6. Lizbetin, J.; Hlatka, M.; Bartuska, L. Issues concerning declared energy consumption and greenhouse gas emissions of FAME biofuels. Sustainability 2018, 10, 3025. [CrossRef]

7. Zhang, L.W.; Yang, Y.; Sun, M.H.; Liu, H. Energy management strategy based on dynamic programming for dual source trolleybus. Teh. Vjesn. Tech. Gaz. 2017, 24, 1439-1447.

8. European Commission. 2020 Climate \& Energy Package. Available online: https://ec.europa.eu/clima/ policies/strategies/2020_en (accessed on 19 May 2018). 
9. Lodi, C.; Seitsonen, A.; Paffumi, E.; Gennaro, M.; Huld, T.; Malfettani, S. Reducing $\mathrm{CO}_{2}$ Emissions of Conventional Fuel Cars by Vehiclephotovoltaic Roofs. 2018. Available online: https://reader.elsevier.com/ reader/sd/06B97658021746555534D41EB2E86B290AA (accessed on 18 May 2018).

10. Erixon, F. The Europe 2020 Strategy: Time for Europe to Think Again. 2010. Available online: http: //journals.sagepub.com/doi/full/10.1007/s12290-010-0120-8 (accessed on 18 May 2018).

11. European Commission. 2030 Climate \& Energy Framework. Available online: https://ec.europa.eu/clima/ policies/strategies/2030_en (accessed on 18 May 2018).

12. Rohrer, J. Time for Change: $\mathrm{CO}_{2}$-the Major Cause of Global Warming. 2007. Available online: https: //timeforchange.org/CO2-cause-of-global-warming (accessed on 18 May 2018).

13. European Commission. 2050 Low-Carbon Economy. Available online: https://ec.europa.eu/clima/policies/ strategies/2050_en (accessed on 18 May 2018).

14. Bukova, B.; Brumercikova, E.; Kondek, P. Determinants of the EU transport market. In Proceedings of the 2016 International Conference on Engineering Science and Management, Zhengzhou, China, 13-14 August 2016; pp. 249-252.

15. Ondrus, J.; Karon, G. Video System as a Psychological Aspect of Traffic Safety Increase. In Proceedings of the 17th International Conference on Transport Systems Telematics (TST), Katowice, Poland, 5-8 April 2017; pp. 167-177.

16. European Commission. Transport: EU Transport White Paper. Available online: https://ec.europa.eu/clima/ policies/international/paris_protocol/transport_en (accessed on 19 May 2018).

17. Bogale, B.D. Handbook of Research on Sustainable Development and Governance Strategies for Economic Growth in Africa; ICI Global Disseminator of Knowledge: Pennsylvania, PA, USA, 2018; pp. 416-442.

18. Gasparik, J.; Siroky, J.; Peceny, L.; Halas, M. Methodology for assessing the quality of rail connections on the network. Komunikacie 2014, 16, 25-30.

19. Gogola, M. The analysis of traffic impact on urban environment in city of Zilina. Log. Sci. J. Trans. Log. 2010, 1, 44-52.

20. Schröder, S.; Liedtke, G.T. Towards an integrated multi-agent urban transport model of passenger and freight. Res. Transp. Econ. 2017, 64, 3-12. [CrossRef]

21. Žaglinskis, J.; Rapalis, P.; Lazareva, N. An overview of Natural Gas Use in Ships: Necessity and Engine Supply. Period. Polytech. Transp. Eng. 2018, 46, 185-193. [CrossRef]

22. Alam, M.S.; Hyde, B.; Duffy, P.; McNabola, A. Analysing the Co-Benefits of transport fleet and fuel policies in reducing $\mathrm{PM}_{2.5}$ and $\mathrm{CO}_{2}$ emissions. J. Clean. Product 2018, 172, 623-634. [CrossRef]

23. Hlatka, M.; Bartuska, L. Comparing the Calculations of Energy Consumption and Greenhouse Gases Emissions of Passenger Transport Service. Nase More 2018, 65, 224-229. [CrossRef]

24. Jurkovic, M.; Kalina, T.; Teixeira, A.F. Possibilities of using alternative fuels for transport solution in Brazil. In Proceedings of the 21st International Scientific Conference TRANSPORT MEANS 2017, Kaunas, Lithuania, 20-22 September 2017; pp. 724-728.

25. Milojevic, S. Sustainable application of natural gas as engine fuel in city buses-Benefit and restrictions. J. Appl. Eng. Sci. 2017, 15, 81-88. [CrossRef]

26. Mintzia, D.; Kehagia, F.; Tsakalidis, A.; Zervas, E. A methodological framework for the comparative analysis of the environmental performance of roadway and railway transport. Promet Traffic Transp. 2018, 30, 721-731. [CrossRef]

27. Moro, A.; Lonza, L. Electricity carbon intensity in European Member States: Impacts on GHG emissions of electric vehicles. Transp. Res. Part D 2018, 64, 5-14. [CrossRef]

28. Pawełczyk, M.; Szumska, E. Evaluation of the efficiency of hybrid drive applications in urban transport system on the example of a medium size city. In Proceedings of the 13th International Conference on Modern Electrified Transport, MET 2017, Warsaw, Poland, 5-7 October 2017.

29. Milojevic, S.; Milojević, S.; Skrucany, T.; Milošević, H.; Stanojević, D.; Pantić, M.; Stojanović, B. Alternative drive systems and environmentally friendly public passengers transport. Appl. Eng. Lett. 2018, 3, 105-113. [CrossRef]

30. Austriatech. 2019. Available online: https://www.austriatech.at/en/news/electromobility-with-expertise (accessed on 8 February 2019).

31. Babić, D.; Bajor, I.; Babić, M.I. Choice factors of distribution channels. J. Transp. Logist. 2010, 1, 5-13. 
32. Hoerstebrock, T.; Hahn, A.; Sauer, J. Tool based assessment of electromobility in urban logistics. Stud. Comput. Intell. 2014, 537, 379-395.

33. Carbon, C.C.; Gebauer, F. The Safe-Range-Inventory (SRI): An assistance tool for optimizing the charging infrastructure for electric vehicles. Traffic Psychol. Behav. 2017, 47, 101-113. [CrossRef]

34. Harrison, G.; Thiel, C. An exploratory policy analysis of electric vehicle sales competition and sensitivity to infrastructure in Europe. Technol. Forecast. Soc. Chang. 2017, 114, 165-178. [CrossRef]

35. Plötz, P.; Gnann, T.; Sprei, F. Can policy measures foster plug-in electric vehicle market diffusion? In Proceedings of the EVS 2016-9th International Electric Vehicle Symposium 2016, Montreal, QC, Canada, 19-22 June 2016.

36. Seixas, J.; Simões, S.; Dias, L.; Kanudia, A.; Fortes, P.; Gargiulo, M. Assessing the cost-effectiveness of electric vehicles in European countries using integrated modeling. Energy Policy 2015, 80, 165-176. [CrossRef]

37. Zubaryeva, A.; Thiel, C.; Barbone, E.; Mercier, A. Assessing factors for the identification of potential lead markets for electrified vehicles in Europe: Expert opinion elicitation. Technol. Forecast. Soc. Chang. 2012, 79, 1622-1637. [CrossRef]

38. Electric Cars Exceed $1 \mathrm{~m}$ in Europe as Sales Soar by More Than 40\%. The Guardian 2018. Available online: https://www.theguardian.com/environment/2018/aug/26/electric-cars-exceed-1m-in-europe-as-salessoar-by-more-than-40-per-cent (accessed on 13 February 2019).

39. Cobb, J. The World Just Bought Its Two-Millionth Plug-in Car. 2017. Available online: https://www.hybridcars. com/the-world-just-bought-its-two-millionth-plug-in-car/ (accessed on 10 December 2018).

40. Rievaj, V.; Synak, F. Does electric car produce emissions? Sci. J. Sil. Univ. Technol. Ser. Transp. 2017, 94, 187-197. [CrossRef]

41. Li, S.; Li, J.; Li, N.; Gao, Y. Vehicle Cycle Analysis Comparison of Battery Electric Vehicle and Conventional Vehicle in China. In Proceedings of the International Powertrains, Fuels and Lubricants Meeting, FFL 2013, Seoul, Korea, 21-23 October 2013.

42. Moro, A.; Helmers, E. A new hybrid method for reducing the gap between WTW and LCA in the carbon footprint assessment of electric vehicles. Int. J. Life Cycle Assess. 2017, 22, 4-14. [CrossRef]

43. Pero, F.D.; Delogu, M.; Pierini, M. Life Cycle Assessment in the Automotive Sector: A Comparative Case Study of Internal Combustion Engine (ICE) and Electric Car. In Proceedings of the 47th International Conference on Stress Analysis, AIAS 2018, Villa San Giovanni, Italy, 5-8 September 2018; pp. 521-537.

44. Saenz-Esteruelas, J.; Figliozzi, M.; Serrano, A.; Faulin, J. Electrifying last-mile deliveries: A carbon footprint comparison between internal combustion engine and electric vehicles. In Proceedings of the 1st International Conference on Smart Cities, Smart-CT 2016, Malaga, Spain, 15-17 June 2016; pp. 76-84.

45. Ahn, S.W. EU member-states' reaction to the climate change in transportation: French case of the development of electric vehicles. J. Contemp. Eur. Stud. 2019, 37, 103-127.

46. Astegiano, P.; Fermi, F.; Martino, A. Investigating the impact of e-bikes on modal share and greenhouse emissions: A system dynamic approach. In Proceedings of the 21st Euro Working Group on Transportation Meeting (EWGT 2018). Transp. Res. Procedia 2019, 37, 163-170. [CrossRef]

47. Lu, M.J.; Taiebat, M.; Xu, M.; Hsu, S.C. Multiagent spatial simulation of autonomous taxis for urban commute: Travel economics and environmental impacts. J. Urban Plan. Dev. 2018, 144, 04018033. [CrossRef]

48. Biresselioglu, M.E.; Kaplan, M.D.; Yilmaz, B.K. Electric mobility in Europe: A comprehensive review of motivators and barriers in decision making processes. Transp. Res. Part A-Policy Pract. 2018, 109, 1-13. [CrossRef]

49. Plötz, P.; Gnann, T.; Jochem, P.; Yilmaz, H.U.; Kaschub, T. Impact of electric trucks powered by overhead lines on the European electricity system and $\mathrm{CO}_{2}$ emissions. Energy Policy 2019, 130, 32-40. [CrossRef]

50. Blyankinshtein, I.; Askhabov, A.; Voevodin, E.; Kashura, A.; Malchikov, S. Concept and models for evaluation of black and white smoke components in diesel engine exhaust. Transp. Probl. 2017, 12, 83-91.

51. Mukherjee, D.; Rajvanshi, A. Application of Strategic Environmental Assessment as a Land Use Planning Tool in India: A Case of Gurgaon-Manesar Development Plan, Haryana, India. J. Environ. Assess. Policy Manag. 2016, 18, 1650017. [CrossRef]

52. Stoilova, S. Study of the efficiency of motorail trains as a factor in transport development. In Proceedings of the 3rd International Multidisciplinary Scientific Conference on Social Sciences and Arts SGEM 2016, Albena, Bulgaria, 22-31 August 2016; pp. 627-634. 
53. Methodology for Calculation and Declaration of energy Consumption and GHG Emissions of Transport Services (Freight and Passengers); European Standard EN 16 258:2012; European Association for Forwarding, Transport, Logistics and Customs Services (CLECAT): Bruxelles, Belgium, 2012.

54. European Commission. Technical Annex to the SEAP Template Instructions Document: The Emission Factors; The European Commission: Bruxelles, Belgium, 2012.

55. Skrúcaný, T.; Milojević, S.; Semanová, Š.; Čechovič, T.; Figlus, T.; Synák, F. The Energy Efficiency of Electric Energy as a Traction Used in Transport. Transp. Tech. Technol. 2018, 14, 9-14. [CrossRef]

56. European Commission. DG ENER, Unit A4, Energy Datasheets: EU28 Countries. 2018. Available online: https://ec.europa.eu/energy/en/data/energy-statistical-pocketbook (accessed on 20 January 2019).

57. IAEA Bulletin. Changing realities. Int. At. Energy Agency 1998, 1, 3.

58. Slovak Ministry of the Economy. Decree No. 88/2015 of the Ministry of Economy of the Slovak Republic. Laying Down the Scope of Evaluation, Method of Calculation and Value of Energy Efficiency of Sources and Distribution; Slovak Ministry of the Economy: Bratislava, Slovakia, 2015.

59. Electropedia-Battery and Energy Technologies-Energy Efficiency. 2019. Available online: https://www. mpoweruk.com (accessed on 20 January 2019).

60. Decarbonisation Pathways, Publication of Eurelectric (Iniciative of Energy Industry in Europe). 2018. Available online: https://cdn.eurelectric.org/media/3457/decarbonisation-pathways-h-5A25D8D1.pdf (accessed on 15 December 2018).

61. European Reference Life Cycle Database. 2012. Available online: http://lca.jrc.ec.europa.eu/lcainfohub/ datasetArea.vm (accessed on 20 January 2019).

62. Covenant of Mayors. Reporting Guidelines on Sustainable Energy Action Plan and Monitoring, Version 1.0; European Commission: Bruxelles, Belgium, 2014.

63. Spritmonitor.de. Verbrauchswerte Real Erfahren. Available online: https://www.spritmonitor.de (accessed on 12 February 2019).

64. Skrúcaný, T.; Semanová, Š.; Figlus, T.; Šarkan, B.; Gnap, J. Energy intensity and GHG production of chosen propulsions used in road transport. Communications 2017, 19, 3-9.

65. Global EV Outlook. Scaling Up the Transition to Electric Mobility. 2019. Available online: https: //www.iea.org/publications/reports/globalevoutlook2019/ (accessed on 5 September 2019).

66. Publications Office of the EU. EU Energy in Figures. Statisticalpocketbook 2018; Office of the European Union: Luxemburg, 2018.

(C) 2019 by the authors. Licensee MDPI, Basel, Switzerland. This article is an open access article distributed under the terms and conditions of the Creative Commons Attribution (CC BY) license (http://creativecommons.org/licenses/by/4.0/). 